INTERNATIONAL JOURNAL FOR

HISTORY, CULTURE AND MODERNITY

www.history-culture-modernity.org

Published by: Uopen Journals

Copyright: () The Author(s).

Content is licensed under a Creative Commons Attribution 4.0 International Licence

elSSN: 2213-0624

\title{
Introduction: Life Writing and European Identities
}

\author{
Marijke Huisman and Marleen Rensen
}

HCM 7: 1049-1066

DOI: $10.18352 / \mathrm{hcm} .595$

\begin{abstract}
Since the turn of the millennium, life writing has been a burgeoning field, with identity formation as one of its key themes. In terms of identity 'Europe' is still relatively understudied, despite the fact that biographies and autobiographies have long been used to constitute or foster European identities, as is the case, for example, with respect to the so-called 'founding fathers' of the EU. Life writing bears at least as much potential to challenge such master narratives of Europe and make an important contribution to the ongoing debate about European identity. This special issue on life writing and European identity illustrates this, in articles ranging from Ai Weiwei's art exhibition \#SafePassage (20I6) and the (contested) dichotomy of Western and Eastern European modernity in Vesna Goldsworthy's memoir Chernobyl Strawberries (2005), to life in post-war Norway in Karl Ove Knausgard's bestselling novel cycle Min Kamp (2009-20 I I) and the meta-biographical work of novelist A.S. Byatt.
\end{abstract}

Keywords: Europe, identity formation, life writing, literature

In 20 I 6, the British literary writer A.S. Byatt was awarded the Erasmus Prize for her 'remarkable contribution to life writing'. 'The jury praised her intellectually rich and diverse oeuvre of novels, biographies, short stories and essays, in which reflections on biography and portraiture hold a prominent place. Possession: A Romance (I990) and The Biographer's Tale (20I0) are the most obvious examples of Byatt's 
innovative ways of exploring the process of biographical writing. Both novels narrate, though in different ways, how scholarly researchers take possession of the historical figures they investigate. Byatt illuminates how biographers immerse themselves in the lives and thoughts of others to the point where the boundaries between self and other, reality and imagination blur. The jury further appreciated her ingenious engagement with Europe's cultural traditions and history of ideas. Throughout her career, Byatt has constantly created new narrative forms to reflect on life, art and science, while dealing with important figures, events or epochs in European history. In her most recent essay Peacock and Vine (20I6), Byatt entwines the lives and works of two artists, William Morris and Mariano Fortuny. Highlighting the differences between the 'Nordic' Morris from Britain and the 'Southern' Fortuny from Spain, she suggests that they changed decorative arts and design in nineteenthcentury Europe, each in their own way. In this essay, as in many of her other writings, Byatt's interest in writing lives, and in thinking about writing lives, is connected to a certain idea of European culture.

In the essay 'How I became European', Byatt relates how literature awakened her sense of Europeanness. The stories of Homer, Dante, Racine, Goethe and Proust provided her with an imaginative entry into cultural forms available outside of Britain. It is through reading that she came to feel European at least as much as English, she writes. ${ }^{2}$ Teaching literature in America further confirmed her identification with Europe. An informal enquiry into the ways Europeans understand their own identities led her to realize that all Europeans share 'a sense of a deep and complicated past'. ${ }^{3}$ Modern European literature, as Byatt sees it, articulates this awareness by re-telling ancient stories and myths to engage readers in new narratives about Europe and its complex history and cultural geography. Byatt's own work, which is inscribed in this European tradition, provides ample opportunity to reflect on practices of storytelling and on (re)constructions of the past that we need to make sense of people's lives, both individually and collectively. This special issue collects four contributions on life writing and European identities. ${ }^{4}$

\section{Life Writing}

The practice of writing lives is not exclusive to modern times. In the second century Plutarch wrote Parallel Lives, in which he described 
lives and characters of notable Greeks and Romans to commemorate and emulate. In the same spirit, medieval authors wrote lives of saints (hagiographies) and religious-secular leaders like popes, bishops and kings. Early modern biographers further expanded the range of biographical subjects to include notable scholars, writers and others, but their era gave rise to a new cultural practice too: the 'self-biography'. From the I770s, new words like 'self-biography' and 'auto-biography' became mainstream in European languages. ${ }^{5}$ Since the late eighteenth century, moreover, a remarkably broad range of people have written their own life stories, men and women, from all ranks of society. ${ }^{6}$ Printed books were initially the main vehicles for this auto/biographical output, but the media revolutions of the twentieth and twenty-first centuries resulted in new forms for an age-old practice to document life: biopics (movies), blogs, Facebook posts, and so on.

In contrast to the long tradition of writing lives, academic studies of life writing are still young. Leading journals like Biography: An Interdisciplinary Quarterly and $a / b$ : Auto/Biography Studies were established only in 1978 and 1985 respectively, while the International Auto/Biography Association (IABA) was founded in I999. By then, terminology quickly changed and 'life writing' emerged in titles of new academic journals and research centres such as the Centre for Life History and Life Writing Research (1999) at the University of Sussex, the Australian journal Life Writing (2004), the Centre for Life-Writing Research at King's College in London (2007), the Oxford Centre for Life-Writing at Wolfson's College (20I I), the North American journal Lifewriting Annual: Biographical and Autobiographical Studies (20I I), the European Journal of Life Writing (20I2), and the research group Life Sciences - Life Writing at Johannes Gutenberg Universität in Mainz (20I4).

This infrastructure notwithstanding, 'life writing' is notorious for its lack of definition. Surveying the field, however, it is clear that 'life writing' was introduced as a more inclusive alternative to genre classifications like 'biography', 'autobiography', 'memoir', 'diary' and 'letter'. In the Encyclopedia of Life Writing. Autobiographical and Biographical Forms (200I), for instance, editor Margaretta Jolly wrote that 'life writing' was chosen as an umbrella term 'because of its openness and inclusiveness across genres, and because it encompasses the writing of one's own or another's life', even 'originating outside of the written form, including testimony, artifacts, reminiscence, personal narrative, visual 
arts, photograph, film, oral history, and so forth' ${ }^{7}$ In a similar effort for openness and inclusion, Sidonie Smith and Julia Watson, in their leading textbook Reading Autobiography. A Guide for Interpreting Life Narratives (200I), understand 'life writing' as a 'general term for writing of diverse kinds that take a life as its subject' ${ }^{8}$ Such writings can be fictional (autofiction), but life writing scholars tend to concentrate on 'the large and ever expanding set of practices people employ to represent actual lives, their own and others'. ${ }^{9}$

Practices of life writing can be studied by scholars from virtually all disciplines and 'life writing' self-identifies as an interdisciplinary field that ranges from the humanities to social and life sciences. In practice, the scene is dominated by scholars from the humanities - more specifically by scholars housed at departments for language, literature and creative writing, gender, race, queer and disability studies, cultural and media studies, and memory studies. In general, moreover, biographical forms of life writing receive significantly less attention than autobiographical forms. ${ }^{10}$ In order to further outline the field, we therefore focus on developments in studies of 'autobiography'.

Remarkably, autobiographical writing has been practised much longer than studied. ${ }^{\text {II }}$ Until at least the second half of the twentieth century literary scholars did not see autobiography as a viable subject, because this kind of writing was not recognized as a literary genre. Influenced by New Criticism, twentieth-century literary critics shifted their focus from context to text until the point that authors were proclaimed redundant and dead. Twentieth-century historians, on the other hand, grew ever more suspicious of the subjectivity and creativity, hence trustworthiness, of documents that earlier historians had used as historical sources: autobiographies, memoirs and the like. Once the discipline moved towards the social sciences and historiographical fashion shifted from 'individuals' to 'structures' in the mid-twentieth century, documents of individual lives became next to irrelevant for historians.

Still, some lone academic wolves turned against the tides of their disciplines. Dutch historian Jacques Presser, for instance, launched the concept 'egodocuments' in the I950s and propagated their use in historical research. ${ }^{12}$ He practised what he preached in Ashes in the Wind. The Destruction of Dutch Jewry (I968), ${ }^{13}$ but fellow historians condemned his (bestselling) studies for the use of 'subjective' sources. 
Literary scholars, on the other hand, grew gradually more interested in these texts, precisely because they were no longer seen as mere historical recordings. In 1968, for example, Comparative Literature Studies featured an article by Stephen A. Shapiro who called for studies into 'the dark continent of literature: autobiography', and claimed that 'Now is the time to examine the meaning and value of individual life' ${ }^{14}$ In I 980 , the cultural moment was once more proclaimed by James Olney, in a volume that set the stage for 'autobiography studies' and is still recycled in anthologies and other overviews of the field. ${ }^{15}$

In his effort to connect 'autobiography studies' to the 'cultural moment', Olney did not mention the rise of Holocaust testimonies, which would stimulate later critics to label the late twentieth century as 'the age of memoir', 'the era of the witness' or the 'age of testimony' ${ }^{16}$ Olney mentioned two other factors instead. First, he pointed to the identity politics of academic programmes that accompanied contemporary emancipation movements, like Black Studies, African Studies and Women's Studies. Striving for counter histories and literatures, scholars found autobiographical texts to provide 'access to an experience $\ldots$ that no other variety of writing can offer' ${ }^{17}$ Second, and most important to Olney, was a contemporary 'fascination with the self, an anxiety about the dimness and vulnerability of that entity that no one has ever seen or touched or tasted' ${ }^{18}$ Olney somewhat echoed Shapiro, who saw studies of life narratives as means to rescue individual, human subjectivity from mass media, institutionalization and other effects of modernization.

In establishing the new field, older studies of autobiography were rediscovered and used to build a critical framework that conceptualized autobiography as both a literary and a modern genre. This is once more illustrated by Olney's introduction to the I980 volume, in which he reprinted older studies that laid the 'foundations'. In his introductory overview, Olney claimed that critical literature on autobiography started in 1956, when French philosopher Georges Gusdorf published the essay 'Conditions et limites de l'autobiographie' (I956) and argued for the anthropological and literary significance of autobiography. In Gusdorf's view, the anthropological significance rested on the idea that autobiography expressed an existential search for meaning and could not begin to exist before the rise of individual self-consciousness. Critics should therefore move 'beyond truth and falsity' and 
give up thinking about autobiography in the same way as we do an objective biography, regulated only by the requirements of the genre of history. Every autobiography is a work of art and at the same time a work of enlightenment; it does not show us the individual seen from outside in his visible actions but the person in his inner privacy, not as he was, not as he is, but as he believes and wishes himself to be and to have been. What is in question is a sort of revaluation of individual destiny; the author, who is at the same time the hero of the tale, wants to elucidate his past in order to draw out the structure of his being in time. ${ }^{19}$

Gusdorf built on the work of German philosopher and historian Georg Misch, who spent his life on Die Geschichte der Autobiographie (I907-I969). In this massive, multi-volume but unfinished book, Misch contended that autobiography, defined as a self-written account of an individual's life, did not develop until the late Middle Ages or Renaissance. Misch, in turn, built on the work of cultural historian Jacob Burckhardt who, in I860, had argued that only Renaissance culture in Italy had lifted a medieval 'veil' that was 'woven of faith, illusion and childish prepossession' and awakened man as 'a spiritual individual' who 'recognized himself as such' ${ }^{20}$

In the early stages of autobiography criticism, a conception of 'self' as an autonomous, self-reflexive individual became critical to understandings of the genre. By framing autobiography as a literary genre that testified to processes of individualization and secularization, autobiography became also associated with modernization and modernity. Gusdorf had mentioned another crucial element, though: 'being in time'. Karl Weintraub, in particular, picked up on this point in I978, when he argued that the autobiographical genre could not really develop before the late eighteenth or early nineteenth century because historicism, the idea that true knowledge of the world and man can only be obtained through historical studies into origins and developments, was another necessary condition for autobiography. ${ }^{2 \mathrm{I}}$ Combining individualism and historicism as necessary preconditions, autobiography critics thus located their object of studies in modern Europe - gradually shifting the birth of the genre from the Renaissance to the late eighteenth century.

In order to elevate autobiography into a relevant category for literary studies, further energy was spent on defining the genre and establishing a canon. Based on criteria such as the level of individualism, 
subjective introspection and quality of writing, 'autobiography' was separated from other, lesser-valued types of life writing like conversion narratives or 'memoirs' and 'biography' - the latter two being considered historical instead of literary genres. In this process, some autobiographies were canonized as capturing both the human condition and the best or greatest in the genre. This canon ranged from 'precursors' like St. Augustine's spiritual autobiography Confessions (c. 400) and the Vita by Italian Renaissance men Benvenuto Cellini (I500-I57I) and Girolamo Cardano (I5OI-I576) to modern autobiographies like Jean-Jacques Rousseau's Les Confessions (I782-9), Johann Wolfgang von Goethe's Dichtung und Wahrheit (I8I I-30) and twentieth-century examples like Les Mots (I964) by Jean-Paul Sartre.

It did not take long before this white and male canon was criticized by scholars engaged in the studies that co-created the 'cultural moment' for autobiography studies. Feminist, post-colonial and other critics aimed to diversify the autobiographical canon by adding other texts, but also urged to reconsider underlying definitions of the genre and the self. Feminist scholars, for instance, claimed that women's conception of self were better understood in terms of relationality than of individuality. ${ }^{22}$ Women, in other words, were considered to (have been socialized to) see themselves not as autonomous individuals but as related to other people, in their families or communities. This could also explain why life narratives written by women often looked less like 'autobiographies' and more like 'memoirs' or even 'biographies'. In order to include texts by women and other marginalized human subjects (including most men), it thus became increasingly apparent that hierarchical genre classifications had to be abandoned and new, more inclusive concepts introduced - like 'auto/biography' and 'life writing'.

Influenced by postmodern theories of language, scholars of auto/ biography studies simultaneously radicalized the idea of autobiography as a creative act and came to see lives, selves, identities and experiences as results of autobiographical acts or performances. One major source of inspiration was the work of Joan Scott who, in 'The Evidence of Experience' (I99I), objected against emancipatory histories that used first-person narratives to document the lives and experiences of women, gays or black people. In her view, such histories reproduced categories of difference as natural or given. Instead, she argued for studies that would historicize these categories by asking which experiences 
are (not) recognized as relevant or telling and how social identities are (re)constructed in (historical) narratives. ${ }^{23}$ In the nineties, scholars in auto/biography studies gradually moved beyond the text into its context to understand how creative and performative constructions of lives, selves and identities were defined and bound by discursive and material possibilities. In this process, the terminology shifted once more because the concept 'life writing' enabled scholars to focus less on genre and more on the practice of communicating a life and a self.

Since the turn of the millennium, 'life writing' is a burgeoning field of studies that has given rise to academic journals, international networks and research centres, as we indicated earlier. In contemporary culture, too, life narratives abound: from books in both offline and online stores to oral and audio-visual testimonies at display in historic museums or stored in (digital) archives, to reality TV programmes, biopics, internet blogs, Facebook posts, Instagram selfies and so on. ${ }^{24}$ Ben Yagoda, in Memoir: A History (2009), even argued that '[m]emoir has become the central form of the culture: not only the way stories are told, but the way arguments are put forth, products and properties marketed, ideas floated, acts justified, reputations constructed or salvaged' ${ }^{25}$ Responding to this culture, life writing scholars have expanded their territory far beyond traditional concepts of a text and include for example graphic novels, (self-) portraits in paint or other media, and most importantly: digital lives. In the process, former research priorities like individualist selfconceptions and genre have faded, whilst new themes and perspectives are developed, from ethical and legal questions about privacy and surveillance of auto/biographical data to post-human conceptions of life writing. ${ }^{26}$

\section{European Identities}

Europe is a relatively new research theme in life writing studies. The European branch of the International Association for Auto/Biography Association (IABA) has actively fostered research on life writing matters in Europe since its foundation in 2009. ${ }^{27}$ As Philippe Lejeune observed, a European association was needed because life writing research is fragmented and organized in separate disciplinary, national and linguistic spheres. ${ }^{28}$ The difficulties in assessing the wealth of life 
writing sources across Europe is partly related to the varied national traditions of collecting and archiving life writing texts. Scholars and archivists are now making collaborative efforts to advance the study of life writing in Europe by facilitating comparative research. For instance, some of the diary archives that emerged since the mid-I980s across Europe ${ }^{29}$ have formed a network. ${ }^{30}$ It is a profound challenge to connect their collections and make them accessible and comparable to scholars across the continent and beyond. Another challenge is to study life writing archives as 'sites of knowledge production' which can help uncover European history in all its complexity. ${ }^{3 \mathrm{I}}$

Long before Europe became a topic of academic interest to life writing scholars, biographies and autobiographies have been used to constitute or foster European identities. Precisely because Europe is a reality difficult to grasp, life narratives of real 'Europeans' are considered powerful resources that can make the abstract concrete and help bring about identification. The myth of Europe's 'founding fathers' clearly illustrates this. Since the early stages of European integration, biographies of Monnet, Schuman and the like have been written to tell the story of Europe as an idealistic project of peace and unification. Similar to the American model, where the founding fathers are at the heart of the narrative about the birth of the nation, their lives serve to commemorate the origins of European integration..$^{32}$ In line with the earliest EU attempts to promote a European identity, they were presented as 'euro-symbols', exemplifying European values and principles. ${ }^{33}$ In his book The European Rescue of the Nation-State (1992) economic historian Alan Milward devotes a full chapter to these 'great men' and argues that the stories of their lives are often told in a manner remarkably comparable to saints' legends. The history of European integration is falsely represented, he writes, by 'the miraculous doings of these European saints, as recited by disciples and set down in hagiographies' ${ }^{34}$ Biographies stress their commitment to a new, post-national European order, whereas, in fact, they were driven by national interests at least as much as by European idealism.

Even if contemporary biographers offer a more nuanced picture of the origins of European integration, the myth of the founding fathers is perpetuated through museums, exhibitions and monuments, of which most are (co-)funded by the EU. The private houses of Monnet, Schuman and Adenauer have turned into museums and the recently opened House 
of European History in Brussels keeps alive their memory as icons of European integration as well. Recently, in 20I8, Simone Veil, the French politician and first president of the European Parliament, was commemorated as a 'Mother' of Europe, with an exposition in front of the Berliamont building in Brussels. The large banners with photos and quotes from her autobiography Une vie (2007), referring to her experiences as a holocaust survivor, a lawyer and European politician, cast her life as a narrative of reconciliation and human rights. Typical for the EU's current approaches to the alleged 'crisis' of European identity, the aim is to make Europeans aware of the history they share. ${ }^{35} \mathrm{In}$ recent years attempts have been made to shape a more inclusive narrative of Europe by drawing attention to the lives of ordinary citizens. Some exhibitions, for instance, make use of video testimonies of citizens from different EU member states who tell about their experiences of reconciliation and integration. As critics have noted, though, the selection of citizens is often not quite representative of Europe's diversity and stresses foremost the benefits of integration. In order to engage more and other citizens in the narration of Europe's history, the prevailing trend in museums is to encourage visitors to tell their own life stories, thus stimulating a sense of inclusion and belonging. ${ }^{36}$

Apart from the uses of life narratives for the top-down promotion of a master narrative of Europe, life writing bears at least as much potential to challenge this narrative by looking at the various ways people have tried to make sense of Europe in their own life stories. Since auto/biographies record individual experiences from all social strata, at all times, and from different localities across the continent, they can reveal the multitude of different perceptions of Europe. It is generally accepted by scholars across disciplines that Europe is no fixed entity; it is understood and experienced in a wide variety of ways throughout history. Clearly, Europe is not identical to the European Union. Whoever tries to define Europe in terms of geography, history or culture will inevitably be confronted with historical transformations, shifting borders and a plurality of beliefs and values across time and place. To this can be added that views vary, as they always have, on the cultural specificity of Europe in relation to Asia and Africa and 'other' civilizations. Despite the fact that defining Europe is tricky and difficult, it is a reality in the lives of many people. In his book Formations of European Modernity: A Historical and Political Sociology of Europe (2013), Gerard Delanty emphasizes 
that an understanding of Europe should go beyond the observation that it 'takes a plurality of forms' ${ }^{37} \mathrm{He}$ makes a case for seeing Europe as a world historical region which generated particular social and cultural forms through the process of development. Ideas of Europe and European identities may be viewed as inventions or constructions, he argues, but one should not forget that they produce real effects and thus contribute to the formation of Europe. Considering all this, it makes more sense to explore modes of identifications with Europe than examining 'the' European identity. As life narratives, and memoirs and autobiographies in particular, express an understanding of self and identity, they can offer valuable insight into how Europeans perceive Europe, how they negotiate this (non-)belonging to their global, national and regional attachments and how this might have affected the shape of long-term cultural and social structures.

One approach in life writing studies with a focus on Europe is to examine the auto/biographical works of canonized artists and intellectuals who give life and substance to a European identity. A prime example is Stefan Zweig's posthumously published Die Welt von Gestern. Erinnerungen einers Europäers (1942). The memoir of this Jewish-Austrian writer expresses his identification with a cosmopolitan, humanist and tolerant Europe, defined against the narrow nationalism that increasingly dominated the age in which he lived. Keeping alive a certain idea(l) of Europe has also motivated other authors to record their life histories. Naturally, the identifications with Europe they articulate diverge according to the political and cultural context in which they write. The Polish-Lithuanian writer Czeslaw Milosz, for instance, published his memoir Rodzinna Europa (I959), literally 'familiar Europe' or 'native Europe', during the Cold War, when he lived in exile in America. His life story voices a sense of belonging to East Central Europe. This region, as Milosz saw it, belonged to the Eastern bloc politically speaking, but it was closely connected to the West in terms of culture. It was his aim to inform Western readers about life in this other part of Europe and (re-)connect the region to the West.

Current life writing scholars are equally moving away from the perspective of the elite and the (Western) core of the continent by studying Europe from 'below' and from the 'margins'. This is evidently part of a larger historiographical current, which brings into focus the view of those excluded and oppressed, for reasons of social class, race, gender, 
sexuality, religion or geography. Firstly, a project worth mentioning here is 'Life writing "From Below" in Europe', which brings together a group of international scholars who investigate and compare the writing of letters, diaries and memoirs in working class environments across Europe.$^{38}$ Exploring together such sources from various countries does not only provide new insight into working conditions and experiences of poverty, but also into family life, religious practices and national and regional belonging. They furthermore allow the study of the diverse life writing forms and practices of peasants, artisans, industrial workers and other groups who belong to the lower social strata of European societies.

Secondly, various scholars are making more visible the 'Eastern' perspective on Europe by drawing attention to the auto/biographies from post-communist Europe that have been published in growing numbers over the last decades. Life writing plays a significant role in the process of coming to terms with the communist past and redefining relations to the region and nation as well as to Europe. The (non-)belonging and longing for Europe is a central theme in many life narratives from the former Eastern 'bloc'. They engage with issues of a common European memory and identity and present their oftentimes alternative view and experience of history in the twentieth century. Some authors redefine their position on the continent and perform a European identity, whereas others challenge or reject such modes of identification. ${ }^{39}$

Thirdly, and equally significant, is the growing attention for the life stories of refugees and migrants, from within or outside of the continent, that challenge the dominant narrative of Europe as a project of human rights and universal values. Postcolonial literature and life writing studies especially contribute to altering perspectives on Europe and the EU through the investigation of stories of migrants from Africa and the Middle East, who have entered the continent to seek asylum. Many stories tell how their dreams of Europe are shattered by real-life experiences of 'Fortress Europe' as a hostile space of inequality, exploitation and racism. ${ }^{40}$ The belief that life narratives have an extraordinary capacity to engage an audience and appeal to the readers' faculties of empathy and identification can partly explain that the refugee crisis has given impetus to numerous oral history projects, which invite migrants and refugees to share their stories, experiences and perceptions of Europe..$^{4 I}$ 
Recording their lives makes it possible to put a name and a face to statistics, to recognize each individual as part of Europe's history, and to build, stimulate or secure their 'agency'. The study of refugee and migrant stories, in oral or written form can make an important contribution to the ongoing debate about European identity.

\section{The Articles}

The four contributions in this volume relate to the themes and topics described above. Anna Poletti examines how new forms of life writing can open up critical perspectives on Europe. She shows that Ai Weiwei addresses the issue of migration in contemporary Europe by making use of digital life narrative forms in art. Focusing on the exhibition \#SafePassage (20I6), Poletti analyzes how the Chinese artist exposes photographs and videos for the testimony and witnessing of the violation of human rights. Images of his personal experience of political violence, intimidation and surveillance by Chinese authorities are, among others, related to the series of selfies he took with refugees who arrived in Europe at the Greek island of Lesbos. Her article brings out well how Weiwei's art makes a strong ethical appeal for the humane treatment of refugees in Europe through his engagement with new digital forms of (self) life writing.

Gabriele Linke's article connects to the Eastern European theme in life writing studies and offers an analysis of Vesna Goldsworthy's memoir Chernobyl Strawberries (2005). The life story of Goldsworthy, who grew up in the former Yugoslavia in the I96os and migrated to England in the I 980 s, makes an excellent case study for closely examining representations of life in the 'Western' and 'Eastern' bloc. Taking 'modernity' as a key concept for analysis, Linke investigates how she deals with the (contested) dichotomy of Western capitalist modernity and Eastern socialist modernity. She highlights that Goldsworthy stresses commonalities, rather than differences, between her life experiences under these two different political systems. Linke suggests that, due to her multiple cultural alignments, Goldsworthy is able to negotiate differences between modernities and ascertain a fluid cosmopolitan and pan-European identity based on an understanding of the condition of modernity as something shared by Europeans across the East/West divide. 
Odile Heynders shifts the scene to representations of life in NorthEuropean society with her reading of Karl Ove Knausgård's bestselling novel cycle Min Kamp (My Struggle). While his self-narration evokes the tradition of confessional life writing, this literary project is an experimental form of self-narration. Unlike other authors before him, Knausgård immerses the reader in the everyday banalities of his private life. Focusing on the three themes of family, freedom and man/woman roles, Heynders shows that he stresses the uniqueness of his intimate story but simultaneously locates himself in the social environment of the modern middle class in postwar Norway. Her analysis of the final volume of the cycle, which offers lengthy reflections on Hitler's autobiography Mein Kampf, illustrates how Knausgård links up his own, single life story to the broader history and social make-up of Europe.

Max Saunders continues on the literary plane and leads us back to A.S. Byatt's engagement with life writing forms. He analyzes how Byatt's fiction reflects on the biographical quest by playing with the conventions of biography. Her way of writing is distinctly different from the postmodern historical novel and from bio-fiction, even though it has a similar way of combining an air of historical reality with the suggestion that the truth of someone's life and history cannot be known outside stories. Resisting the use of real historical figures as characters in novels, Saunders argues, her engagement with life writing is unique in its extraordinarily wide range of invention. For example, for Possession: A Romance, Byatt not only invented the two fictional Victorian poets who are the subjects of biographical investigation, but she also created some of their letters and poems and other pieces of writing, that serve as sources for the study of their lives. With such 'meta-biographical' and 'meta-fictional' writings, Byatt brings into focus the story of stories. Although she is very wary of a biographical reading of her work, Saunders suggests, with references to her novel Ragnarok, that she does at least leave her readers with the story of herself as a writer who is shaped by the world of tales and myths she encountered through the old Norse stories she devoured as a child in Britain in the I940s.

\section{Notes}

I Annual Report Erasmus Prize 2016 (http://www.erasmusprijs.org/library/ publicaties/Jaarverslag_20I6_Eng_Def.pdf). 
2 A.S. Byatt, 'Hoe ik Europees werd', Nexus 42, Europees Testament (2005), I 25-36.

3 A.S. Byatt, 'What is a European?', The New York Times (I3 October 2002).

4 The articles in this special issue are based on papers presented at a conference on 'Life Writing and European Identities' on the occasion of the awarding of the Erasmus Prize to A.S Byatt, held in Utrecht, the Netherlands, on I6 November 2016.

5 Robert Folkenflik, 'Introduction. The Institution of Autobiography' in: Robert Folkenflik (ed.), The Culture of Autobiography. Constructions of Self-Representation (Stanford, I993) I-20.

6 For this reason, autobiographical writing is often considered as the most democratic form of writing. G. Thomas Couser, Memoir. An Introduction (Oxford, New York, 20I2) 26; Bonnie J. Gunzenhauser, 'Autobiography: General Survey' in: Margaretta Jolly (ed.), Encyclopedia of Life Writing. Autobiographical and Biographical Forms (London, Chicago, 2002).

7 Margaretta Jolly (ed.), Encyclopedia of Life Writing. Autobiographical and Biographical Forms (London, Chicago, 2002) ix.

8 Sidonie Smith and Julia Watson, Reading Autobiography. A Guide for Interpreting Life Narratives (Minneapolis, London, 200I) 3.

9 Couser, Memoir, 24.

Io Binne de Haan, 'The Eclipse of Biography in Life Writing', Hans Renders and Binne de Haan (ed.), Theoretical Discussions of Biography. Approaches from History, Microhistory, and Life Writing (Lewiston, Queenston, Lampeter, 2013) 265-293; also Barbara Caine, Biography and History (New York, 20I0).

I I Smith and Watson, Reading Autobiography, I I I-63; Arianne Baggerman, Rudolf Dekker and Michael Mascuch, 'Egodocuments and History: a Short Account of the Longue Durée', The Historian (2016) I I-45.

I 2 Rudolf Dekker, 'Jacques Presser's Heritage: Egodocuments in the Study of History', Memoria y Civilazación 5 (2002) I3-27.

I3 The original Dutch title is Ondergang. De vervolging en verdelging van het Nederlandse Jodendom, I94O-I945 (I965).

I4 Stephen A. Shapiro, 'The Dark Continent of Literature: Autobiography', Comparative Literature Studies 5 ( I968) 42 I-54, at 454.

I5 James Olney, 'Autobiography and the Cultural Moment: A Thematic, Historical, and Bibliographic Introduction', James Olney (ed.), Autobiography: Essays Theoretical and Critical (Princeton, I980) 3-27. This essay is most recently reprinted in: Ricia Anne Chansky and Emily 
Hipchen (ed.), The Routledge Auto/Biography Studies Reader (New York, 20I6) 5-I4.

I6 See for instance: Shoshana Felman and Dori Laub, Testimony. Crises of Witnessing in Literature, Psychoanalysis, and History (New York, I992) 6, 206; Leigh Gilmore, The Limits of Autobiography. Trauma and Testimony (Ithaca, 200 I ) I6-7, Annette Wieviorka, The Era of the Witness (Ithaca NY, 2006); Fuyuku Kurasawa, The Work of Global Justice. Human Rights as Practices (Cambridge, 2007) 23.

I 7 James Olney, 'Autobiography and the Cultural Moment', 8.

I 8 Ibid., I 2.

I9 Georges Gusdorf, 'Conditions and Limits of Autobiography', The Routledge Auto/Biography Studies Reader, 24-30, at 27-8.

20 Jacob Burckhardt, The Civilization of the Renaissance in Italy (New York, I958) I43.

2 I Karl Weintraub, The Value of the Individual Self. Self and Circumstance in Autobiography (Chicago, I978). On connections between the notion of individual self, autobiography and modernity, see also: Charles Taylor, Sources of the Self. The Making of the Modern Identity (Cambridge, I989); Peter Gay, The Naked Heart (New York, London, I995); Michael Mascuch, Origins of the Individualist Self. Autobiography and Self-Identity in England, I59I-I79I (Cambridge, I997); Dror Wahrman, The Making of the Modern Self. Identity and Culture in Eigteenth-Century England (New Haven, London, 2004); Jerrold Seigel, The Idea of the Self. Thought and Experience in Western Europe since the Seventeenth Century (Cambridge, 2005).

22 Estelle C. Jelinek (ed.), Women's Autobiography. Essays in Criticism (Bloomington, I980); Sidonie Smith and Julia Watson (eds), 'Introduction: Situating Subjectivity in Women's Autobiographical Practices', Smith and Watson, Women, Autobiography, Theory. A Reader (Madison, I998) 3-52; Sidonie Smith and Julia Watson, Life Writing in the Long Run (Michigan, 20I6), part V: 'Women's Life Writing in the United States', 485-604.

23 Joan W. Scott, 'The Evidence of Experience', Critical Inquiry I7 (I99I) 773-97. More recently Verónica Tozzi raised the same critique in 'The Epistemic and Moral Role of Testimony', History and Theory 5I (20I2) I-I 7.

24 Anna Poletti and Julie Rak (eds), Identity Technologies. Constructing the Self Online (Madison, 20 I4).

25 Ben Yagoda, Memoir: A History (New York, 2009) 7. 
26 For an overview of new themes and perspectives: 'Looking Forward. The Futures of Auto/Biography Studies', special of the journal $a / b$ : Auto/ Biography Studies 32:2 (2017).

27 The proceedings of the founding conference of IABA Europe are collected in: Marijke Huisman, Anneke Ribberink, Monica Soeting and Alfred Horning (eds), Life Writing Matters in Europe (Heidelberg, 2012).

28 Philippe Lejeune, 'A Plea for a Guide to Autobiographical Europe', Lecture at the Founding Conference of IABA Europe Life Writing in Europe (29 October 2009), I-IO (https://www.autopacte.org/8 I amsterdamangl.pdf).

29 Marijke Huisman, 'Monuments for the Common (Wo)Man: Diary Archives in Europe. Interview with Monica Soeting, Co-Founder of the Dutch Diary Archive'. Tijdschrift voor Genderstudies, I9:3 (2016) 373-87, at 383-4.

30 The European Diary Archives and Collections Network (EDAC) was founded in June, 20I5. Philippe Lejeune, 'Europe's Treasure Hunters. The Founding of a Network of European Diary Archives and Collections', European Journal of Life Writing 4 (20I5) I6-8; see also http://www.edaceu.eu/?page_id=2 (accessed I4 October 20I9).

3I Leena Kurvet-Käosaar, 'The Archive', Auto/Biography Studies 32: 2 (20I7), 355-358.

32 Wolfram Kaiser, 'From Great Men to Ordinary Citizens? The Biographical Approach to Narrating European Integration in Museums', Culture Unbound. Journal of Current Cultural Research 3 (20I I), 385-400.

33 Chris Shore, Building Europe. The Cultural Politics of European Integration (New York, [2000], 40-66.

34 Alan Milward, The European Rescue of the Nation-State (London, New York, 2000 [1992]), 3I8.

35 Ann Rigney, 'Transforming Memory and the European Project', New Literary History 43:4 (2012), 607-28.

36 Kaiser, 'From Great Men to Ordinary Citizens?', 392-6.

37 Gerard Delanty, Formations of European Modernity: A Historical and Political Sociology of Europe (Houndmills, 2013), 9.

38 See the cluster of articles on 'Life Writing "From Below" in Europe', European Journal of Life Writing 7 (20I8) (https://ejlw.eu/issue/ view/4392).

39 Ioana Luca and Leena Kurvet-Käosaar, ' Life Writing Trajectories in PostI989 Eastern Europe', European Journal of Life Writing, volumes 2 (2013) and 3 (20I4). 
40 See for example, Elisabeth Bekers, Maggie Ann Bowers and Sissy Heff, 'Imaginary Europes, Phantoms of the Past, Conceptions of the Future?', in: Journal of Postcolonial Writing 5I:2 (2015), I27-3I.

4I There is, for example, the Bodies Across Borders in Europe project, initiated by Luisa Passerini, with the ambition to foster a better understanding of how migrants identify with Europe (https://babe.eui.eu/). Another example is the European Refugees Oral History Project Specially Unknown/Ongekend Bijzonder, which collects stories of refugees in France, Germany, Italy and the Netherlands (https://speciallyunknown.eu/).

\section{About the Authors}

Marijke Huisman, co-founder of the European chapter of the International Auto/Biography Association (IABA Europe), is assistant professor of Public History, Education and Civic Engagement at Utrecht University in the Netherlands. Her research focuses on relationships between public and academic forms of doing history, in particular on (auto)biographical representations of the past. She has published books on autobiographical practices of writing history in the nineteenth century, on the use of slave narratives in public and academic dealings with the history and legacy of slavery in Great Britain, the United States and the Netherlands, and on the history of the feminist and queer bookstore Savannah Bay in Utrecht. E-mail: m.h.huisman@uu.nl

Marleen Rensen is assistant professor of Modern European Literature at the University of Amsterdam in the Netherlands. Her research focuses on literature and life writing in the twentieth and twenty-first centuries, with particular attention to the biographies and autobiographies of artists and intellectuals. She has published widely about the articulation of European and transnational identities in the life writing texts of French, German and Austrian writers between I900 and I950 (including Romain Rolland, Stefan Zweig and Klaus Mann). E-mail: M.J.M.Rensen@uva.nl 